\title{
PATHOGENIC ASPECTS OF EPIDERMOPHYTON FLOCCOSUM LANGERON ET MILOCHEVITCH AS A POSSIBLE AETHIOLOGICAL AGENT OF TINEA CAPITIS
}

\author{
Danielle Patrícia Cerqueira Macêdo; Rejane Pereira Neves*; Oliane Maria Correia Magalhães; \\ Cristina Maria de Souza-Motta; Lusinete Aciole de Queiroz
}

Departamento de Micologia, Centro de Ciências Biológicas, Universidade Federal de Pernambuco, Recife, PE, Brasil

Submitted: May 21, 2004; Returned to authors for corrections: December 06, 2004; Approved: March 28, 2005

\section{SHORT COMMUNICATION}

\begin{abstract}
The aim of this research was to verify the ability of 15 isolates of Epidermophyton floccosum to perforate hair in vitro and characterize them for pathogenicity factors such as growth at $37^{\circ} \mathrm{C}$ and proteinase and phospholipase production. Fourteen isolates perforated hair and from these twelve produced perforating organs. All isolates grew at $37^{\circ} \mathrm{C}$ and produced proteinase, but not phospholipase. These results suggest that E. floccosum may be a possible aethiological agent of tinea capitis.
\end{abstract}

Key words: Epidermophyton floccosum, tinea capitis, pathogenicity

Epidermophyton floccosum is an anthropophilic dermatophyte with a world-wide distribution in the tropics and subtropics, that frequently causes tinea cruris, tinea pedis, tinea corporis and onychomycosis (5). Some authors have used the ability to invade hair in vitro as a taxonomic tool to distinguish the different genera and species of dermatophytes which can attack the hair $(1,7,11)$.

It has been suggested that growth temperature and activity of extracellular enzymes such as proteinase and phospholipase are involved in fungi pathogenicity $(5,12)$. The aim of this research was to verify the ability of isolates of E. floccosum to perforate hair in vitro and characterize them for pathogenicity factors such as growth at $37^{\circ} \mathrm{C}$ and proteinase and phospholipase production.

Fifteen isolates of E. floccosum were included in the investigation: eight isolates provided by Medical Mycology Laboratory, Federal University of Pernambuco, Brazil and seven maintained under mineral oil $(2873,3182,3345,4150,4151,4798$, 4799) at URM Culture Collection of Department of Mycology.

Our procedure was based on Vanbreusegham (11) and English (4) modified techniques in which pieces of hair about 2 $\mathrm{cm}$ long, weighting $0.05 \mathrm{~g}$, were placed in Petri dishes and then autoclaved. A suspension containing the test microorganism was transfered to the Petri dishes with the sterilized hair. At the same time a control study was performed, in duplicate. The preparations were then maintained at room temperature and incubated at $37^{\circ} \mathrm{C}$ for 20 days without hydrating. For direct examination hair segments were removed from the plates and placed in a drop of lactophenol cotton blue mounting fluid and examined under the microscope.

Each isolate was placed on the surface of Sabouraud dextrose agar medium in duplicate contained in Petri dishes, one incubated at $37^{\circ} \mathrm{C}$ and the other at room temperature $\left(28^{\circ} \mathrm{C}\right)$ and the growth observed for 10 days.

For detection of proteinase and phospholipase activities, the proposed methods from Lacaz et al. (5) and Price et al. (8) respectively, with modifications, were used: modified the cultures were transferred to the center of a Petri dish containing Sabouraud agar medium added of $1 \mathrm{M}$ sodium chloride, $0.005 \mathrm{M}$ calcium chloride and two natural egg yolks, replacing the "egg yolk" of Difco Laboratories. Cultures were observed for 15 days for formation of a halo.

Keratinolytic activity was verified in $14(93.3 \%)$ isolates. Six were active at room temperature, one at $37^{\circ} \mathrm{C}$, seven at both temperatures and one only showed no activity. From these, twelve produced perforating organs. The course of hair invasion was clearly observed in our studies. A series of photographs 
exhibiting a hair under attack by E. floccosum is shown in Fig. 1. Cabañes et al. (2) verified similar in vitro keratinolytic activity of E. floccosum; however the isolates did not produce perforating organs. Some authors rarely relate the involvement of $E$. floccosum as aethiological agent of tinea capitis. On the other hand, the incapacity of this specie in perforating hair is frequently cited $(9,10)$. Such cases of tinea capitis due to this specie are interesting because these episodes confirm the sporadic reports of hair parasitism in vivo by this dermatophyte (3).

All E. floccosum isolates grew at $37^{\circ} \mathrm{C}$. Some authors have described $30^{\circ} \mathrm{C}$ as an ideal temperature for this specie (5).

Proteinase activity was verified in all isolates at the $15^{\text {th }}$ day of observation, in both temperature conditions, through the formation of a transparent halo around the colony. The halo remained after the addition of a acidified solution of mercury

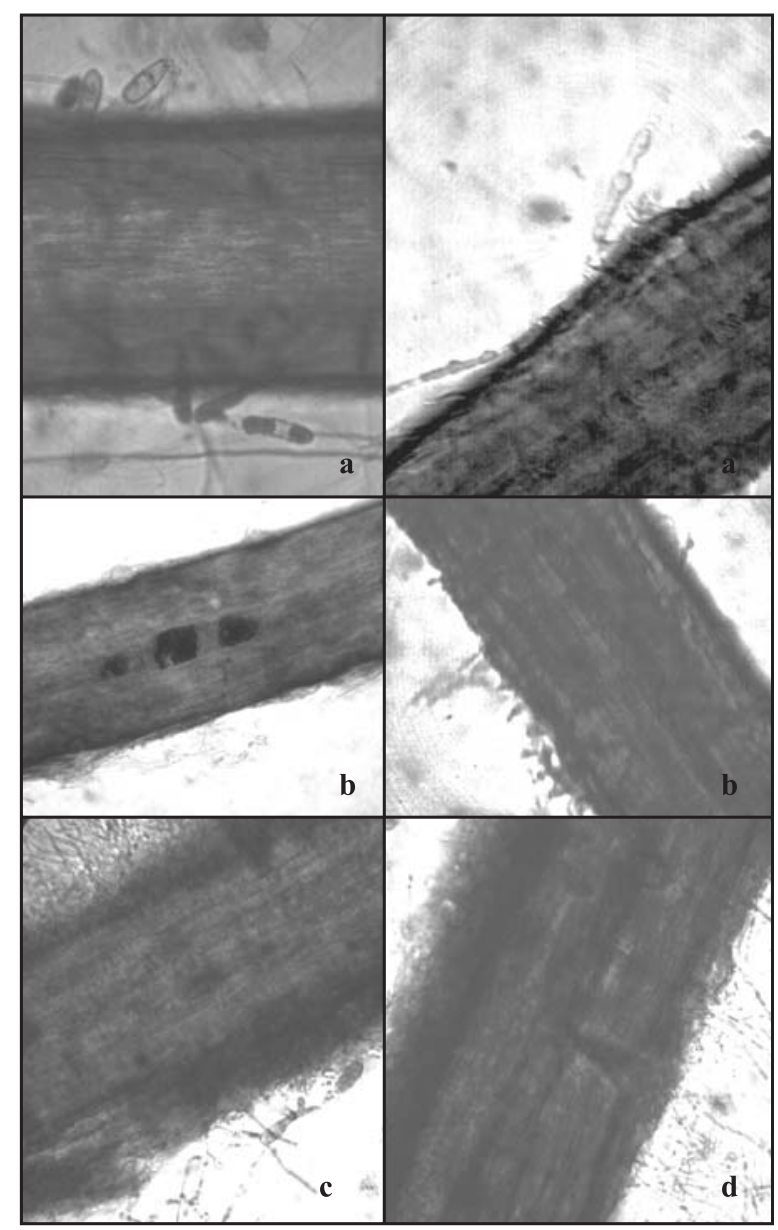

Figure 1. Perforation and perforating organs produced by Epidermophyton floccosum: (a) hypha and macroconidia attached to hair cortex; (b) surface erosion of the cortex; (c) early stage of formation of the perforating organs and macroconidia; (d) perforating organ reaching the hair medule. chlorate, indicating true proteolysis and degradation of casein. However, according to Minocha et al. (6), proteolytic activity of E. floccosum isolates is lower than other dermatophytes.

None of the E. floccosum isolates presented phospholipase activity. No previous study about this enzyme activity was developed with $E$. floccosum before.

\section{RESUMO}

\section{Aspectos patogênicos de Epidermophyton floccosum langeron et milochevitch como possível agente de tinea capitis}

O propósito desta pesquisa foi verificar a capacidade de 15 isolados de Epidermophyton floccosum perfurarem cabelo in vitro e caracterizar quanto a fatores de patogenicidade como crescimento a $37^{\circ} \mathrm{C}$ e produção de proteinase e fosfolipase. Dos isolados, 14 perfuraram o cabelo tendo 12 formado órgãos de perfuração. Todos os isolados cresceram a $37^{\circ} \mathrm{C}$ e secretaram proteinase, mas não fosfolipase. Nossos resultados sugerem $E$. floccosum como possível agente etiológico de tinea capitis.

Palavras-chave: Epidermophyton floccosum, tinea capitis, patogenicidade

\section{REFERENCES}

1. Ajello, L.; George, L.K. In vitro hair cultures for differentiating between atypical isolates of Trichophyton mentagrophytes and T. rubrum. Mycopathology., 8: 3-17, 1957.

2. Cabañes, F.J.; Abarca, L.; Bragulat, M.R; Calvo, M.A. Further observations on the Keratinolytic activity of isolates of the genus Epidermophyton. Mycopathologia., 98, 41-43, 1987.

3. Difonzo, E.M.; Cappugi, P.; Moretti, S.; Panconesi, E. Kerion-like tinea barbae caused by Epidermophyton floccosum. Mykosen., 28, 365-368, 1985.

4. English, M.P. Destruction of hair by two species of Chrysosporium. Br. Mycol. Soc., 66, 357-358, 1976

5. Lacaz, C.S.; Porto, E.; Martins, J.E.C.; Vaccari, E.M.H.; Melo, N.T. Tratado de Micologia Médica. Sarvier, São Paulo, 2002, 1104 p.

6. Minocha, Y.; Pasricha, J.S.; Mohapatra, L.N.; Kandhari, K.C Proteolytic activity of dermatophytes and its role in the pathogenesis of skin lesions. Sabouraudia, 10, 79-85, 1972.

7. Padhye, A.A.; Young, C.N.; Ajello, L. Hair perforation as a diagnostic criterion in the identification of Epidermophyton, Microsporum and Trichophyton species. Fifth International Conference on the Mycoses, Caracas, 1980, 115-120p.

8. Price, M.F.; Walkison, I.D.; Gentry, L.O. Plate method for detection of phospholipase activity in Candida albicans. Sabouraudia, 20, 7-14, 1982.

9. Romano, C. Case reports. Four paediatric cases of tinea capitis due to unusual agents. Mycoses, 42, 421-425, 1999.

10. Sidrim, J.J.C.; Rocha, M.F.G. Micologia médica à luz de autores contemporâneos. Guanabara Koogan, Rio de Janeiro, 2004, 388p.

11. Vanbreuseghem, R. Keratin digestion by dermatophytes: a specific diagnostic method. Mycologia, 44, 176-182, 1952.

12. Weitzman, I.; Summerbell, R.C. The dermatophytes. Clin. Microbiol. Rev., 8, 240-259, 1995. 